\title{
Tetracycline Resistance in Enterococci and Escherichia coli Isolated from Fresh Produce and Why it Matters
}

\author{
Zahra S. Al-Kharousi ${ }^{a^{*}}$, Nejib Guizani ${ }^{\mathrm{a}}$, Abdullah M. Al-Sadi ${ }^{\mathrm{b}}$, And Ismail M. \\ Al-Bulushi ${ }^{\mathrm{a}}$ \\ ${ }^{\text {a }}$ Department of Food Science and Nutrition, College of Agricultural and Marine Sciences, Sultan Qaboos \\ University, P.O. Box 34, Al Khod, 123, Oman \\ b Department of Plant Sciences, College of Agricultural and Marine Sciences, Sultan Qaboos University, Oman, \\ P.O. Box 34, Al Khod, 123, Oman \\ ${ }^{*}$ Corresponding author \\ umohaned@squ.edu.om \\ TEL: +96824143622
}

Received: 25 June 2020; Published online: 18 Octover 2021

\begin{abstract}
The contamination of fresh produce with antibiotic-resistant bacteria is of particular concern as they are often eaten raw and can be a source for foodborne diseases. Tetracyclines have been largely used in humans, animals and plants which might have accelerated microbial resistance to them. Enterococci and Escherichia coli can be used as indicators to monitor contamination of the fresh produce with tetracycline-resistant bacteria. The investigation related to this issue is very scarce in Oman.This study aimed at identifying tetracycline-resistant enterococci and $E$. coli in fresh produce at the market place. Thirty-one enterococci and ten E. coli were isolated from local (Oman) and imported fruits and vegetables $(N=105)$. Using the standard Kirby-Bauer disc diffusion method, resistance to tetracycline was found in 6 (19\%) enterococci, isolated from cucumber, lettuce and radish, and $5(50 \%)$ E. coli, obtained from cabbage, lettuce and radish. Genetic analysis revealed the presence of tetracycline resistance genes, tet $(\mathrm{A})$ and $t e t(\mathrm{~K})$, in $E$. coli and tet $(\mathrm{K})$, tet $(\mathrm{L})$ and $\operatorname{tet}(\mathrm{M})$ in enterococci, including Enterococcus sulfureus, Enterococcus mundtii, Enterococcus casseliflavus and Enterococcus faecalis. The integron integrase IntI 1 gene, which is known to facilitate the dissemination of antibiotic resistance genes among bacteria, was detected in 2 isolates of $E$. coli. These results demonstrated the capability of fresh produce to act as a potential source for disseminating tetracycline or possibly other antibioticresistant bacteria through the food chain. Thus, control strategies are needed to reduce exposure of the public to such microorganisms.
\end{abstract}

Keywords: Antibiotic resistance; E. coli ; Enterococcus; Integron; Vegetables; Tetracycline

\section{Introduction}

Tetracyclines (TEs) are amongst the most important antibiotic groups used in medicine (Hernandez et al., 2003). They exhibit a broad spectrum of activity against Gram-positive and Gram-negative bacteria, chlamydiae, rickettsiae, nematodes, mycoplasmas and protozoans. They inhibit protein synthesis in bacterial cells (Hernandez et al., 2003; Markley \& Wencewicz, 2018) by preventing attachment of aminoacyl-tRNA to the acceptor (A) site of the ribosome. However, this attachment is reversible rendering TEs to be bacteriostatic (Kohanski et al., 2010; Roberts, 2005).TEs are used to treat infections in humans and animals, preserve harvested fruits and veg- 


\section{Nomenclature}

ARB antibiotic-resistant bacteria

ARG antibiotic resistance genes
HGT horizontal gene transfer

$\mathrm{TE}(\mathrm{s})$ tetracycline(s) etables, kill insect pests, and as growth promoters for animals (Hernandez et al., 2003). As resistance to TEs occurred shortly after their first clinical use in the 1940 s, new semi-synthetic TEs were generated resulting in the evolution of the TEs scaffold and expansion of their use (Markley \& Wencewicz, 2018).

Genetic acquisition of tet genes is the major cause of resistance to TEs. The tet efflux genes code for membrane-associated proteins that export TE from the cell. Examples include tet $(\mathrm{A}), \operatorname{tet}(\mathrm{B}), \operatorname{tet}(\mathrm{C}), \operatorname{tet}(\mathrm{D}), \operatorname{tet}(\mathrm{K}), \operatorname{tet}(\mathrm{L})$ and tet $\mathrm{A}(\mathrm{P})$. Ribosomal protection proteins are cytoplasmic proteins that protect bacterial ribosomes from the effect of TEs. The $\operatorname{tet}(\mathrm{M}), \operatorname{tet}(\mathrm{O})$ and Otr A are among these proteins. TEs can also be altered enzymatically, resulting in their inactivation by the cytoplasmic protein product of the tet $(\mathrm{X})$ gene (Roberts, 2005). Reduced permeability through alteration or reduced expression of porins or morphological changes and mutation in the ribosome can also lead to tetracycline (TE) resistance (Markley \& Wencewicz, 2018).

Horizontal gene transfer (HGT) among bacteria plays an important role in the dissemination of multidrug resistance, especially when antibiotic resistance genes (ARG) are located on mobile genetic elements such as plasmids and transposons. Transposons contain special gene sequences known as integrons. The gene sequence of an integron serves as a site-specific recombination system allowing it to capture or excise novel genetic elements known as gene cassettes that code for various ARG (Roe \& Pillai, 2003). The integrase enzyme of the integron can insert gene cassettes at a specific site known as the attI site and then express them (Gillings et al., 2009). Romaine lettuce, alfalfa sprouts and Savoy spinach in Canada were demonstrated to harbor antibiotic-resistant bacteria (ARB) that carried integron DNA (Bezanson et al., 2008). Use of the class 1 integrase-encoding gene (IntI 1 gene) has been proposed as a generic marker for anthropogenic contaminants because of its common association with antibiotic resistance in pathogenic and commensal bacteria (Jones-Dias et al., 2016).

Enterococcus bacteria have emerged as potential pathogens due to their multiple drug resistance as a result of their capabilities to acquire antibiotic resistance through mutation and HGT (Johnston \& Jaykus, 2004). Therefore, antibiotic resistance of enterococci should be monitored to identify foods that can impose a real risk to people (Pesavento et al., 2014). E. faecalis, E. faecium E. hirea (Ben Said et al., 2016) and E. coli that were isolated from different produce types were found to be resistant to TE (Ben Said et al., 2016; Campos et al., 2013). Many outbreaks have been linked to specific strains of $E$. coli such as E. coli O157:H7 in ready-to-eat salads in 2013 (CDC, 2014a) and E. coli O121 in raw clover sprouts in 2014 (CDC, 2014b). Treating infections becomes more complicated when the causative agent of an outbreak is resistant to antibiotics as well (O'Flahertya et al., 2019).

The prevalence of antibiotic-resistant bacteria was found to vary among countries due to various factors such as the type of antibiotics used (Chewapreecha, 2014). In Oman, TE-resistant $E$. coli was previously isolated from the oviductal fluid of green turtles (Al-Bahry et al., 2012) and chicken (Al-Bahry et al., 2012) but TE-resistance has not been previously investigated in produceassociated bacteria. The aim of this study was to identify phenotypic and genotypic TE resistance in enterococci and E. coli that we previously isolated from different types of locally pro- 
Tetracycline resistance of enterococci and E. coli from produce $\mid 361$

duced and imported fresh produce. The E. coli isolates were also screened for the presence of the IntI 1 gene. The results of this study can help in understanding one of the routes of human exposure to TE-resistant bacteria through consumption of fresh produce. This may be used to develop control strategies to reduce exposure of the public to ARB through food consumption.

\section{Materials and Methods}

\subsection{Sample collection and bacterial isolation and identification}

Isolation and identification of enterococci and $E$. coli from different local (39 samples) and imported (66 samples) fresh fruits and vegetables were performed as previously reported (Al-Kharousi et al., 2016). About 93 enterococci isolates and $15 \mathrm{E}$. coli isolates were collected. To avoid analyzing duplicate or clonal bacteria, one typical colony (details can be found by searching the manufacturer's website; http://www.oxoid.com/UK/ blue/index.asp? $\mathrm{c}=\mathrm{UK} \& \mathrm{lang}=\mathrm{EN})$ of the bacterial isolate from each species was selected from each sample (31 enterococci and $10 \mathrm{E}$. coli isolates) for subsequent analysis.

\subsection{Phenotypic screening of enterococci and $E$. coli for resistance to $\mathrm{TE}$}

The standard Kirby-Bauer disc diffusion method described by the Clinical and Laboratory Standards Institute (CLSI, 2015) was used to test the resistance of enterococci and $E$. coli to TE. Mueller-Hinton agar and TE discs were supplied by Oxoid, UK. E. coli ATCC 25922 (TEsusceptible), Enterococcus faecalis ATCC 51299 (TE-susceptible) and E. faecalis ATCC 29212 (TE-resistant) were used as reference control strains. Enterococci were considered to be resistant if the inhibition zone was $\leq 14 \mathrm{~mm}$ while $E$. coli was considered resistant if the inhibition zone was $\leq 11 \mathrm{~mm}$ (CLSI, 2015).

\subsection{Identification of TE resistance genes}

According to the method developed by $\mathrm{Ng}$ et al. (2001), multiplex PCR was used to screen for the presence of 14 tet genes in the isolates that showed phenotypic resistance to TE. The sequences of primers are presented in Table 1 . In brief, the PCR reaction mix contained template DNA at a concentration of $10 \mathrm{ng} / \mu \mathrm{l}$ and sterile Milli-Q water was added to make a total volume of $25 \mu \mathrm{l}$. Primers were supplied by Macrogen, South Korea for tet genes as follows: group I; tet $(\mathrm{B})(0.25 \mu \mathrm{M}), \operatorname{tet}(\mathrm{C})(0.25 \mu \mathrm{M})$ and $\operatorname{tet}(\mathrm{D})$ $(2.0 \mu \mathrm{M})$, group II; $\operatorname{tet}(A)(1.0 \mu \mathrm{M}), \operatorname{tet}(\mathrm{E})(1.0$ $\mu \mathrm{M})$ and tet $(\mathrm{G})(1.0 \mu \mathrm{M})$, group III; tet $(\mathrm{K})(1.25$ $\mu \mathrm{M}), \operatorname{tet}(\mathrm{L})(1.0 \mu \mathrm{M}), \operatorname{tet}(\mathrm{M})(0.5 \mu \mathrm{M}), \operatorname{tet}(\mathrm{O})$ $(1.25 \mu \mathrm{M})$ and $\operatorname{tet}(\mathrm{S})(0.5 \mu \mathrm{M})$, and group $\mathrm{IV}$; $\operatorname{tet} \mathrm{A}(\mathrm{P})(1.25 \mu \mathrm{M}), \operatorname{tet}(\mathrm{Q})(1.25 \mu \mathrm{M})$ and $\operatorname{tet}(\mathrm{X})$ $(1.25 \mu \mathrm{M})$. PCR beads (puReTaq Ready-To-Go PCR beads) were supplied by GE Healthcare, UK. The thermal profile (Veriti 96-well Thermal cycler, Applied Biosystems, Singapore) for the PCR reaction was as follows: stage 1; denaturation at $94^{\circ} \mathrm{C}$ for $5 \mathrm{~min}$, stage 2 ; denaturation at $94^{\circ} \mathrm{C}$ for $30 \mathrm{sec}$, annealing at $55^{\circ} \mathrm{C}$ for $1 \mathrm{~min}$, extension at $72^{\circ} \mathrm{C}$ for $1.5 \mathrm{~min}$ (35 cycles), stage 3 ; final extension at $72^{\circ} \mathrm{C}$ for $10 \mathrm{~min}$ and then kept at $4^{\circ} \mathrm{C}$.

Enterococci and E. coli isolates were screened for the IntI 1 gene according to the previously reported methods (Gaze et al., 2005; Rosser \& Young, 1999). The PCR mixtures were as previously described for the type of primer pairs (described in Table 1). The thermal profile for the $\mathrm{PCR}$ reaction of the IntI 1 gene $(1 \mathrm{pmole} / \mu \mathrm{l}$ of each primer) was as follows: stage 1 ; denaturation at $96^{\circ} \mathrm{C}$ for $5 \mathrm{~min}, 55$ for $1 \mathrm{~min}, 70^{\circ} \mathrm{C}$ for $3 \mathrm{~min}$ (one cycle), stage 2 ; denaturation at $96^{\circ} \mathrm{C}$ for $15 \mathrm{sec}$, annealing at $55^{\circ} \mathrm{C}$ for $30 \mathrm{sec}$, extension at $70^{\circ} \mathrm{C}$ for $3 \mathrm{~min}$ ( 24 cycles), stage 3 ; final extension at $70^{\circ} \mathrm{C}$ for $5 \mathrm{~min}$ and then kept at $4^{\circ} \mathrm{C}$. Five-microliter aliquots of PCR products of tet and IntI 1 genes were analyzed by gel electrophoresis with $2 \%$ agarose (Thermo Scientific, TopVision, USA) and $0.5 \mu \mathrm{g} / \mathrm{ml}$ ethidium bromide (Sigma-Aldrich, USA). Gels were visualized by UV using GelDoc (GeneFlash, Syngene, USA). A 100-bp ladder (Fermetas, 
O'RangeRuler, Thermo Fisher Scientific) was run on each gel as a molecular size marker. The PCR products of tet and IntI 1 genes were sequenced abroad (Macrogen, South Korea). DNA sequences were aligned and analyzed through the ChromasPro program (Version 1.41, Technelysium Pty Ltd) and compared online with those found at the NCBI using the BLAST program. The DNA sequences were submitted to the European Nucleotide Archive (ENA) to be assigned accession numbers.

\subsection{Statistical analysis}

Statistical tests were performed using $\mathrm{JMP}^{\circledR}$ SAS 14.3, USA to identify significant differences that were considered as $P<0.05$. Chi-square analysis was used to test if TE-resistance differed significantly according to the species and the source of enterococci (local or imported) and the source of $E$. coli (local or imported).

\section{Results and Discussion}

\subsection{Prevalence of enterococci and E. coli}

Enterococci were recovered from 31 out of 105 samples (30\%: 12 local out of $39 ; 31 \%$ and 19 imported out of $66 ; 29 \%$ ), including cabbage, cucumber, dates, mango, lettuce, papaya, radish, tomato and watermelon but not banana, pomegranate, carrot or capsicum. E. coli was recovered from 10 samples (10\%: 6 local out of $39 ; 15 \%$ and 4 imported out of $66 ; 6 \%$ ) of cabbage, lettuce and radish. More detailed information on the prevalence and identity of enterococci and the prevalence of $E$. coli can be found in our previous publication (Al-Kharousi et al., 2016).

\subsection{TE-resistance of enterococci}

Nineteen percent (6 isolates out of 31 , from imported samples only) of enterococci were resistant to TE (Fig. 1). These were Enterococcus casseliflavus, E. faecalis, Enterococcus mundtii and Enterococcus sulfureus (Table 2), isolated from cucumber, lettuce and radish. E. casseliflavus had tet(L) and tet(M). The latter was also found in E. faecalis. E. mundtii possessed tet $(\mathrm{L})$ while $E$. sulfureus harbored tet $(\mathrm{K})$ (Table $3)$.

Enterococci are involved in food intoxication and in spreading antibiotic resistance through the food chain (Abriouel et al., 2008), and they are a leading cause of nosocomial infections (Abriouel et al., 2008; Tian et al., 2019). TE-resistant enterococci were previously isolated from different produce types (Ben Said et al., 2016; Campos et al., 2013). Twenty-nine percent of Enterococcus faecium isolated from fresh produce grown in the United States of America were found to be resistant to $\mathrm{TE}$ while all E. faecalis isolates were susceptible to TE (Johnston \& Jaykus, 2004). In this study, resistance to TE was exhibited by six enterococci (19\%) isolated from the imported samples only. These were $E$. casseliflavus, E. faecalis, E. mundtii and E. sulfureus, isolated from cucumber (source: United Arab Emirates; UAE), lettuce (source: Iran and Jordan) and radish (source: China). tet $(\mathrm{K})$ was harbored by E. sulfureus and tet(L) by $E$. casseliflavus and E. mundtii, whilst tet(M) was found in E. casseliflavus and E. faecalis. The tet $(\mathrm{K})$ and tet $(\mathrm{L})$ genes code for efflux proteins while tet $(\mathrm{M})$ codes for ribosomal-protection proteins (Roberts, 2005).

Statistical tests showed that the type of species of enterococci had no significant effect on their resistance to TE; $\chi^{2}(7, \mathrm{~N}=31)=3.00, P=0.8853$. However, the source (local or imported) of enterococci significantly affected the number of TEresistant enterococci $\chi^{2}(1, \mathrm{~N}=31)=4.699, P=$ 0.0302. Actually, all enterococci originated from local samples were susceptible to TE. This may indicate the absence or low levels of TE-resistant enterococci in locally produced fresh produce as compared to those imported from different countries. In particular, TE-resistance was found in enterococci isolated from imported produce from Iran, Jordan, China and the UAE. Information regarding TE-resistance of enterococci associated with fresh produce in these mentioned countries is very limited. The resistance of Enterococcus sp. to most antimicrobials was reported to be more prevalent in China than in European or other Asian countries (Liu et al., 2013). The re- 
Tetracycline resistance of enterococci and E. coli from produce $\mid 363$

Table 1: Primers used for multiplex PCR for screening tetracycline resistance genes (Ng et al., 2001) and the IntI 1 gene (Gaze et al., 2005; Rosser \& Young, 1999)

\begin{tabular}{|c|c|c|}
\hline Targeted gene & Primers sequence 5'-3' & Amplicon size \\
\hline \multirow[t]{2}{*}{$\operatorname{Tet}(\mathrm{A})$} & GCT ACA TCC TGC TTG CCT TC & 210 \\
\hline & CAT AGA TCG CCG TGA AGA GG & \\
\hline \multirow[t]{2}{*}{$\operatorname{Tet}(\mathrm{B})$} & TTG GTT AGG GGC AAG TTT TG & 659 \\
\hline & GTA ATG GGC CAA TAA CAC CG & \\
\hline \multirow[t]{2}{*}{$\operatorname{Tet}(\mathrm{C})$} & CTT GAG AGC CTT CAA CCC AG & 418 \\
\hline & ATG GTC GTC ATC TAC CTG CC & \\
\hline \multirow[t]{2}{*}{$\operatorname{Tet}(\mathrm{D})$} & AAA CCA TTA CGG CAT TCT GC & 787 \\
\hline & GAC CGG ATA CAC CAT CCA TC & \\
\hline \multirow[t]{2}{*}{$\operatorname{Tet}(\mathrm{E})$} & AAA CCA CAT CCT CCA TAC GC & 278 \\
\hline & AAA TAG GCC ACA ACC GTC AG & \\
\hline \multirow[t]{2}{*}{$\operatorname{Tet}(\mathrm{G})$} & GCT CGG TGG TAT CTC TGC TC & 468 \\
\hline & AGC AAC AGA ATC GGG AAC AC & \\
\hline \multirow[t]{2}{*}{$\operatorname{Tet}(\mathrm{K})$} & TCG ATA GGA ACA GCA GTA & 169 \\
\hline & CAG CAG ATC CTA CTC CTT & \\
\hline \multirow[t]{2}{*}{$\operatorname{Tet}(\mathrm{L})$} & TCG TTA GCG TGC TGT CAT TC & 267 \\
\hline & GTA TCC CAC CAA TGT AGC CG & \\
\hline \multirow[t]{2}{*}{$\operatorname{Tet}(\mathrm{M})$} & GTG GAC AAA GGT ACA ACG AG & 406 \\
\hline & CGG TAA AGT TCG TCA CAC AC & \\
\hline \multirow[t]{2}{*}{$\operatorname{Tet}(\mathrm{O})$} & AAC TTA GGC ATT CTG GCT CAC & 515 \\
\hline & TCC CAC TGT TCC ATA TCG TCA & \\
\hline \multirow[t]{2}{*}{$\operatorname{Tet}(\mathrm{S})$} & CAT AGA CAA GCC GTT GAC C & 667 \\
\hline & ATG TTT TTG GAA CGC CAG AG & \\
\hline \multirow[t]{2}{*}{$\operatorname{Tet} A(\mathrm{P})$} & CTT GGA TTG CGG AAG AAG AG & 676 \\
\hline & ATA TGC CCA TTT AAC CAC GC & \\
\hline \multirow[t]{2}{*}{$\operatorname{Tet}(\mathrm{Q})$} & TTA TAC TTC CTC CGG CAT CG & 904 \\
\hline & ATC GGT TCG AGA ATG TCC AC & \\
\hline \multirow[t]{2}{*}{$\operatorname{Tet}(\mathrm{X})$} & CAA TAA TTG GTG GTG GAC CC & 468 \\
\hline & TTC TTA CCT TGG ACA TCC CG & \\
\hline \multirow[t]{2}{*}{ IntI 1} & ATCATCGTCGTAGAGACGTCGG & 892 \\
\hline & GTCAAGGTTCTGGACCAGTTGC & \\
\hline
\end{tabular}


Table 2: Levels of antibiotic resistance in enterococci $(n=31)$ and Escherichia coli $(n=10)$ isolated from fresh fruits and vegetablese

\begin{tabular}{lccccc}
\hline \multirow{2}{*}{ Bacteria species } & \multirow{2}{*}{ Total } & \multicolumn{2}{c}{ Susceptible } & \multicolumn{2}{c}{ Resistant } \\
\cline { 3 - 6 } & & Local & Imported & Local & Imported \\
\hline Enterococcus casseliflavus & 13 & 1 & 10 & 0 & 2 \\
Enterococcus faecalis & 7 & 5 & 0 & 0 & 2 \\
Enterococcus faecium & 2 & 1 & 1 & 0 & 0 \\
Enterococcus gilvus & 1 & 0 & 1 & 0 & 0 \\
Enterococcus hirae & 1 & 1 & 0 & 0 & 0 \\
Enterococcus mundtii & 4 & 2 & 1 & 0 & 1 \\
Enterococcus raffinosus & 1 & 1 & 0 & 0 & 0 \\
Enterococcus sulfureus & 2 & 1 & 0 & 0 & 1 \\
Escherichia coli & 10 & 4 & 1 & 2 & 3 \\
\hline
\end{tabular}

Table 3: Levels of antibiotic resistance in enterococci $(\mathrm{n}=31)$ and Escherichia coli $(n=10)$ isolated from fresh fruits and vegetables

\begin{tabular}{lllll}
\hline Bacteria No. & Identity (PCR) & Source & Gene & Accession \# \\
\hline 1 & E. coli & Cabbage 1*, Oman & tet(A) & LT548573 \\
2 & E. coli & Cabbage 2, Oman & tet(A) & LT548574 \\
4 & E. coli & Lettuce 2, Jordan & tet(A) & LT548575 \\
7 & E. coli & Radish 1, China & tet(A) & LT548576 \\
15 & E. coli & Radish 2, China & tet(A) & LT548579 \\
4 & E. coli & Lettuce 2, Jordan & tet(K) & - \\
27 & E. sulfureus & Lettuce 2, Jordan & tet(K) & - \\
35 & E. casseliflavus & Radish 1, China & tet(L) & LT548584 \\
36 & E. mundtii & Radish 2, China & tet(L) & LT548585 \\
25 & E. casseliflavus & Cucumber 3, UAE & tet(M) & LT548581 \\
26 & E. faecalis & Lettuce 1, Jordan & tet(M) & LT548582 \\
29 & E. faecalis & Lettuce 1, Iran & tet(M) & LT548583 \\
1 & E. coli & Cabbage 1, Oman & IntI 1 & LT548588 \\
7 & E. coli & Radish 1, China & IntI 1 & LT548589 \\
\hline
\end{tabular}

*: Sample number

-: Not available 
Tetracycline resistance of enterococci and E. coli from produce 365

sistance rate of enterococci isolated from clinical samples, in China, to TE was found to be $49.3 \%$, and tet $(\mathrm{M})$ was detected in all TE-resistant isolates, including 22 E. faecalis and 14 E. faecium . Likewise, high resistance rates to TE $(93 \%)$ were reported in enterococci (E. faecalis, E. faecium, E. hirae, E. gallinarum and E. casseliflavus) isolated from chickens and pigs in China (Liu et al., 2013). Enterococci isolated from clinical samples in Iran were also found to be resistant to various antibiotics including TE (Asadollahi et al., 2018). Very limited information is available regarding antibiotic resistance of enterococci (clinical or environmental) in the UAE and Jordan. Potential sources of contamination of fresh produce with ARB include animals, feces, soil, irrigation water, insecticides, fungicides, inadequately composted manure and human (Olaimat \& Holley, 2012). In China, residues of TE and various tet genes, including tet $(A), \operatorname{tet}(\mathrm{B})$, tet $(\mathrm{C}), \operatorname{tet}(\mathrm{E}), \operatorname{tet}(\mathrm{M}), \operatorname{tet}(\mathrm{O}), \operatorname{tet}(\mathrm{S})$ and $\operatorname{tet}(\mathrm{X})$, were found in the irrigation wastewater and soil. Longterm irrigation with wastewater increased the abundance of tet genes in soil (Pan \& Chu, 2018). Thus, the irrigation of vegetables with wastewater in China (Khan et al., 2008) can be a route for transferring ARB to vegetables. Also, the introduced tet genes into soils, if present on the transferable plasmids, may persist for a long time due to HGT and may be transferred to other bacteria or human pathogens (Pan \& Chu, 2018). Likewise, in the UAE, irrigation with wastewater was reported to be a possible route for vegetable microbial contamination (Hussain \& Qureshi, 2020). In Iran, fresh produce was found to have inadequate microbiological quality. Thus, improvements in vegetable production, assessment of contamination of irrigation water and fertilizers, and methods used for the identification of microbial contaminants will be necessary for a safer supply of fresh produce (Soltan Dallal et al., 2015).

\subsection{TE-resistance of $E$. coli}

Resistance to TE (Fig. 1) was found in $5(50 \%)$ $E$. coli isolates (two from local samples; cabbage and three from imported samples; lettuce and radish) (Tables 2 and 3). All of the TE-resistant
$E$. coli harbored the $\operatorname{tet}(A)$ resistance gene. In addition, one $E$. coli that was isolated from lettuce harbored tet $(\mathrm{K})$ (Table 3). The IntI 1 gene was not detected in enterococci but in 2 isolates of $E$. coli ; one originated from local cabbage and the other from radish imported from China (Table 3). The accession numbers that were given to sequences of tet and IntI 1 genes are available at http://www.ebi.ac.uk/ena/data/view/ LT548573-LT548593 accessed June 24, 2020). Sequences of the IntI 1 genes identified in the 2 isolates of $E$. coli were also recorded in the 'INTEGRALL' platform which is dedicated to integrons and can be reached on http://integrall.bio. ua.pt/?acc=LT548588 and http://integrall.bio. ua.pt/?acc $=$ LT548589 (both accessed June 24, 2020).

E. coli can be used as an indicator species to determine the antibiotic resistance state of enteric microorganisms (Teuber, 1999). Resistance to $\mathrm{TE}$ by $E$. coli isolated from vegetables was previously reported in other countries (Hassan et al., 2011). All of the TE-resistant E. coli in the current study harbored $\operatorname{tet}(A)$. One $E$. coli that was isolated from lettuce harbored tet $(\mathrm{K})$. Both of these genes are efflux genes that code for membrane-associated proteins that export TE out of the cell (Ng et al., 2001; Roberts, 2005). There was no significant difference in the frequency of TE-resistant $E$. coli isolated from local and imported samples; $\chi^{2}(1, \mathrm{~N}=10)=1.67$, $\mathrm{P}=0.1967$ and this may indicate similar levels of contamination with TE-resistant E. coli . Investigation of TE-resistance in produce-associated $E$. coli was not previously studied in Oman. TEresistance of animal-associated E. coli was previously studied by Al-Bahry et al. (2013) who found high levels of TE resistance $(97.9 \%$ ) in $E$. coli isolated from the colon of chickens which were collected from three poultry farms in Oman, where the most common TE-resistant determinants were $\operatorname{tet}(A)$ followed by tet $(\mathrm{B})$. In this study, the IntI 1 gene for the class 1 integron was detected in $2 \mathrm{E}$. coli isolates; one obtained from local cabbage and the other from radish imported from China. Jones-Dias et al. (2016) detected the class 1 intergron in Gram-negative bacteria recovered from fresh produce grown in Portugal. The class 1 integron is widespread in Enterobacteriaceae bacteria and often harbors ARG (Jaglic 


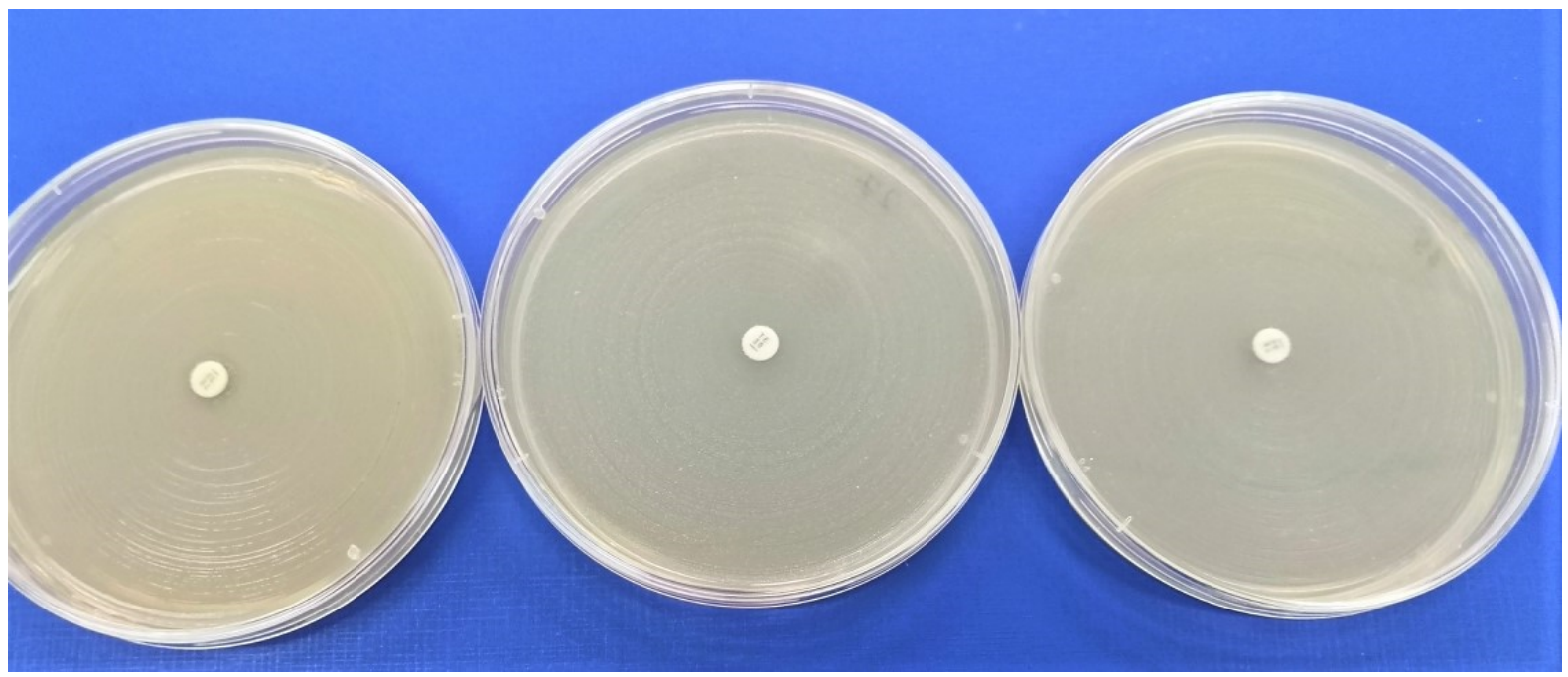

Figure 1: Disc diffusion method showing, from left to right, the resistance of E. coli, E. sulfureus and E. casseliflavus to tetracycline (diameters of growth inhibition zones: 7, 6 and $6 \mathrm{~mm}$, respectively).

\& Cervinkova, 2012). It would be interesting to investigate if TE or other ARG are located on the integrons of the 2 isolates of $E$. coli. Ingestion of foods contaminated with ARG, located on integrons, can facilitate transferof these determinants by HGT and thus influence the pool of antibiotic resistance in humans (Bezanson et al., 2008).

\subsection{Significance of TE resistance in fresh produce-associated enterococci and $E$. coli}

This study demonstrated phenotypic and genotypic TE resistance in enterococci and E. coli isolated from fresh produce ready for consumption. As ARB were also reported to be prevalent in humans and animals, as well as in natural (Gasparrini et al., 2020) and food environments, this may suggest that both pathogenic and commensal microbes have played an important role in spreading ARG, and that the food chain may act as a non-negligible route for bridging the antibiotic resistance between the environment and humans (Li \& Wang, 2010). Different strains of enterococci and E. coli which originate from fresh produce may act as commensals and opportunistic or primary pathogens. Both of them can colonize the human gastrointestinal tract and may cause an opportunistic infection that might happen even years after the ingestion of the contaminated food (Hoelzel et al., 2018). As the results of this study demonstrated the presence of different types of tet genes in enterococci and $E$. coli isolated from fresh produce at the market place, these bacteria may colonize the intestine and affect the tet resistance pool especially if the tet genes can persist in the gut for a long time (Forslund et al., 2013). They also can serve as a vehicle for transfer of tet resistance genes in the intestine (Karami et al., 2006) or in the fresh produce environment before ingestion as was demonstrated to occur in lettuce (Jung \& Matthews, 2016). In fact, in this study, tet(K) was detected in E. sulfureus and E. coli originated from the same lettuce sample (Table 3). It would be interesting to determine if any genetic event occurred between these 2 isolates in lettuce.

Although previous studies reported high levels of TE-resistance in enterococci (Cauwerts et al., 2007) and E. coli (Al-Bahry et al., 2013) from animal sources, DNA is partially degraded by heat, and thus, consumption of raw fresh produce is more likely to deliver a higher concentration of ARG into the gastrointestinal tract 
(Hoelzel et al., 2018). Multidrug-resistant bacteria were previously isolated from various readyto-eat foods (Vincenti et al., 2018), including fresh produce that contained multidrug-resistant enterococci (Johnston \& Jaykus, 2004) and E. coli (Al-Kharousi et al., 2016). Thus, these food commodities, which usually receive no or minimal heat treatment before consumption, may act as a vehicle for transfer of multidrug-resistant enterococci or E. coli to humans (Johnston \& Jaykus, 2004). This transfer may pose a risk to public health as drug resistance can decrease drug efficiency, increase the cost of the treatment of infectious diseases and increase the morbidity and mortality rates (Zhang et al., 2006).

\section{Conclusions}

Half of the isolated E. coli (sources: cabbage, lettuce and radish) were resistant to TE and possessed tet $(A)$ and tet $(\mathrm{K})$ genes. The integron integrase IntI 1 gene was detected in 2 isolates of $E$. coli . This can potentiate the capability of fresh produce to disseminate antibiotic resistance among bacteria especially when these genetic elements are equipped with ARG. About a fifth of the tested enterococci (sources: cucumber, lettuce and radish) were resistant to $\mathrm{TE}$ and possessed tet $(\mathrm{K})$, tet $(\mathrm{L})$ or tet $(\mathrm{M})$ genes. These results demonstrate the contamination of fresh produce with TE-resistant enterococci and $E$. coli . Effective measures are needed to prevent antibiotic-resistant foodborne bacteria from reaching humans.

\section{Acknowledgements}

We thank Sultan Qaboos University (SQU), Oman, for providing the funding for this study.

\section{References}

Abriouel, H., Ben Omar, N., Molinos, A. C., Lopez, R. L., Grande, M. J., MartinezViedma, P., Ortega, E., Canamero, M. M., \& Galvez, A. (2008). Comparative analysis of genetic diversity and incidence of virulence factors and antibiotic resistance among enterococcal pop- ulations from raw fruit and vegetable foods, water and soil, and clinical samples. International Journal of Food Microbiology, 123(1-2), 38-49. https://doi. org/10.1016/j.ijfoodmicro.2007.11.067

Asadollahi, P., Razavi, S. H., Asadollahi, K., Pourshafie, M. R., \& Talebi, M. (2018). Rise of antibiotic resistance in clinical enterococcal isolates during 2001-2016 in iran: A review. New microbes and new infections, 26, 92-99.

Al-Bahry, S. N., Al-Mashani, B. M., Al-Ansari, A. S., Elshafie, A. E., \& Mahmoud, I. Y. (2013). Escherichia coli tetracycline efflux determinants in relation to tetracycline residues in chicken. Asian Pacific Journal of Tropical Medicine, 6(9), 718722. https: / / doi.org / 10.1016/S19957645(13)60125-X

Al-Bahry, S. N., Al-Zadjali, M. A., Mahmoud, I. Y., \& Elshafie, A. E. (2012). Biomonitoring marine habitats in reference to antibiotic resistant bacteria and ampicillin resistance determinants from oviductal fluid of the nesting green sea turtle, chelonia mydas. Chemosphere, 87(11), 1308-1315. https://doi.org/10. 1016/j.chemosphere.2012.01.051

Ben Said, L., Klibi, N., Dziri, R., Borgo, F., Boudabous, A., Ben Slama, K., \& Torres, C. (2016). Prevalence, antimicrobial resistance and genetic lineages of enterococcus spp. from vegetable food, soil and irrigation water in farm environments in tunisia. Journal of the Science of Food and Agriculture, 96(5), 16271633. https://doi.org/10.1002/jsfa.7264

Bezanson, G. S., MacInnis, R., Potter, G., \& Hughes, T. (2008). Presence and potential for horizontal transfer of antibiotic resistance in oxidase-positive bacteria populating raw salad vegetables. International Journal of Food Microbiology, 127(1-2), 37-42. https://doi.org/ 10.1016/j.ijfoodmicro.2008.06.008

Campos, J., Mourao, J., Pestana, N., Peixe, L., Novais, C., \& Antunes, P. (2013). Microbiological quality of ready-to-eat salads: An underestimated vehicle of bacteria and clinically relevant antibiotic 
resistance genes. International Journal of Food Microbiology, 166(3), 464-470. https://doi.org/10.1016/j.ijfoodmicro. 2013.08.005

Cauwerts, K., Decostere, A., De Graef, E. M., Haesebrouck, F., \& Pasmans, F. (2007). High prevalence of tetracycline resistance in enterococcus isolates from broilers carrying the erm(b) gene. Avian Pathology, 36(5), 395-U73. https://doi. org $/ 10.1080 / 03079450701589167$

CDC. (2014a). https:// www . cdc.gov / ecoli / 2013/o157h7-11-13/index.html

CDC. (2014b). https:// www . cdc.gov / ecoli / 2014/o121-05-14/index.html

Chewapreecha, C. (2014). Your gut microbiota are what you eat. Nature Reviews Microbiology, 12(1), 8. https://doi.org/10. 1038/nrmicro3186

CLSI. (2015). https:// www facm. ucl. ac. be / intranet / CLSI / CLSI- 2015- M100- S25. unlocked.pdf

Forslund, K., Sunagawa, S., Kultima, J. R., Mende, D. R., Arumugam, M., Typas, A., \& Bork, P. (2013). Country-specific antibiotic use practices impact the human gut resistome. Genome Research, 23(7), 1163-1169. https://doi.org/10. 1101/gr.155465.113

Gasparrini, A. J., Markley, J. L., Kumar, H., Wang, B., Fang, L., Irum, S., Symister, C. T., Wallace, M., Burnham, C.-A. D., Andleeb, S., Tolia, N. H., Wencewicz, T. A., \& Dantas, G. (2020). Tetracycline-inactivating enzymes from environmental, human commensal, and pathogenic bacteria cause broad-spectrum tetracycline resistance. Communications Biology, 3(1). https:// doi.org/10.1038/s42003-020-0966-5

Gaze, W. H., Abdouslam, N., Hawkey, P. M., \& Wellington, E. M. H. (2005). Incidence of class 1 integrons in a quaternary ammonium compound-polluted environment. Antimicrobial Agents and Chemotherapy, 49(5), 1802-1807. https: // doi.org/10.1128/AAC.49.5.18021807.2005

Gillings, M. R., Holley, M. P., \& Stokes, H. W. (2009). Evidence for dynamic exchange of qac gene cassettes between class 1 integrons and other integrons in freshwater biofilms. FEMS microbiology letters, 296 (2), 282-288.

Hassan, S. A., Altalhi, A. D., Gherbawy, Y. A., \& El-Deeb, B. A. (2011). Bacterial load of fresh vegetables and their resistance to the currently used antibiotics in saudi arabia. Foodborne Pathogens and Disease, 8(9), 1011-1018. https://doi.org/ $10.1089 /$ fpd.2010.0805

Hernandez, M., Borrull, F., \& Calull, M. (2003). Analysis of antibiotics in biological samples by capillary electrophoresis. Tractrends in Analytical Chemistry, 22(7), 416-427. https : / / doi .org / 10.1016 / S0165-9936(03)00702-7

Hoelzel, C. S., Tetens, J. L., \& Schwaiger, K. (2018). Unraveling the role of vegetables in spreading antimicrobial-resistant bacteria: A need for quantitative risk assessment. Foodborne Pathogens and Disease, 15(11), 671-688. https:// doi.org / 10 . 1089/fpd.2018.2501

Hussain, M. I., \& Qureshi, A. S. (2020). Health risks of heavy metal exposure and microbial contamination through consumption of vegetables irrigated with treated wastewater at dubai, uae. Environmental Science and Pollution Research, 27(10), 11213-11226. https:// doi.org/10.1007/s11356-019-07522-8

Jaglic, Z., \& Cervinkova, D. (2012). Genetic basis of resistance to quaternary ammonium compounds-the qac genes and their role: A review. Veterinarni Medicina, 57(6), 275-281. https: / / doi .org / 10.17221/ 6013-VETMED

Johnston, L. M., \& Jaykus, L. A. (2004). Antimicrobial resistance of enterococcus species isolated from produce. Applied and Environmental Microbiology, 70(5), 31333137. https://doi.org/10.1128/AEM.70. 5.3133-3137.2004

Jones-Dias, D., Manageiro, V., Ferreira, E., Barreiro, P., Vieira, L., Moura, I. B., \& Canica, M. (2016). Architecture of class 1,2 , and 3 integrons from gram negative bacteria recovered among fruits and vegetables. Frontiers in Microbiology, 7. 
Tetracycline resistance of enterococci and E. coli from produce $\mid 369$

https : / / doi .org / 10.3389/fmicb. 2016. 01400

Jung, Y., \& Matthews, K. R. (2016). Potential transfer of extended spectrum betalactamase encoding gene, bla(shv18) gene, between klebsiella pneumoniae in raw foods. Food Microbiology, 60, 39-48. https://doi.org/10.1016/j.fm.2016.06. 002

Karami, N., Nowrouzian, F., Adlerberth, I., \& Wold, A. E. (2006). Tetracycline resistance in escherichia coli and persistence in the infantile colonic microbiota. $A n$ timicrobial Agents and Chemotherapy, 50(1), 156-161. https: / / doi .org / 10 . 1128/AAC.50.1.156-161.2006

Khan, S., Cao, Q., Zheng, Y. M., Huang, Y. Z., \& Zhu, Y. G. (2008). Health risks of heavy metals in contaminated soils and food crops irrigated with wastewater in beijing, china. Environmental Pollution, 152(3), 686-692. https:// doi.org/10. 1016/j.envpol.2007.06.056

Al-Kharousi, Z. S., Guizani, N., Al-Sadi, A. M., Al-Bulushi, I. M., \& Shaharoona, B. (2016). Hiding in fresh fruits and vegetables: Opportunistic pathogens may cross geographical barriers. International journal of microbiology, 2016.

Kohanski, M. A., Dwyer, D. J., \& Collins, J. J. (2010). How antibiotics kill bacteria: From targets to networks. $\mathrm{Na}$ ture Reviews Microbiology, 8(6), 423435. https : / / doi . org / 10 . 1038/ nrmicro2333

Li, X., \& Wang, H. H. (2010). Tetracycline resistance associated with commensal bacteria from representative ready-toconsume deli and restaurant foods. Journal of Food Protection, 73(10), 18411848. https: / / doi.org/10.4315/0362028X-73.10.1841

Liu, Y., Liu, K., Lai, J., Wu, C., Shen, J., \& Wang, Y. (2013). Prevalence and antimicrobial resistance of enterococcus species of food animal origin from beijing and shandong province, china. Journal of Applied Microbiology, 114(2), 555-563. https://doi.org/10.1111/jam.12054
Markley, J. L., \& Wencewicz, T. A. (2018). Tetracycline-inactivating enzymes. Frontiers in Microbiology, 9. https : //doi.org/10.3389/fmicb.2018.01058

Ng, L. K., Martin, I., Alfa, M., \& Mulvey, M. (2001). Multiplex pcr for the detection of tetracycline resistant genes. Molecular and Cellular Probes, 15(4), 209-215. https: / / doi.org / 10.1006 / mcpr. 2001. 0363

O'Flahertya, E., Solimini, A. G., Pantanella, F., De Giusti, M., \& Cummins, E. (2019). Human exposure to antibiotic resistantescherichia coli through irrigated lettuce. Environment International, 122, 270280. https:// doi.org/10.1016/j. envint. 2018.11 .022

Olaimat, A. N., \& Holley, R. A. (2012). Factors influencing the microbial safety of fresh produce: A review. Food Microbiology, 32(1), 1-19. https://doi.org/10. 1016/j.fm.2012.04.016

Pan, M., \& Chu, L. M. (2018). Occurrence of antibiotics and antibiotic resistance genes in soils from wastewater irrigation areas in the pearl river delta region, southern china. Science of the Total Environment, 624, 145-152. https://doi.org/10.1016/ j.scitotenv.2017.12.008

Pesavento, G., Calonico, C., Ducci, B., Magnanini, A., \& Lo Nostro, A. (2014). Prevalence and antibiotic resistance of enterococcus spp. isolated from retail cheese, ready-to-eat salads, ham, and raw meat. Food Microbiology, 41. https: //doi.org/10.1016/j.fm.2014.01.008

Roberts, M. C. (2005). Update on acquired tetracycline resistance genes. Fems Microbiology Letters, 245(2), 195-203. https:// doi.org/10.1016/j.femsle.2005.02.034

Roe, M. T., \& Pillai, S. D. (2003). Monitoring and identifying antibiotic resistance mechanisms in bacteria. Poultry Science, 82(4), 622-626. https : / / doi .org / 10 . $1093 / \mathrm{ps} / 82.4 .622$

Rosser, S. J., \& Young, H. K. (1999). Identification and characterization of class 1 integrons in bacteria from an aquatic environment. Journal of Antimicrobial 
Chemotherapy, 44(1), 11-18. https:// doi.org/10.1093/jac/44.1.11

Soltan Dallal, M. M., Shojaei, M., Sharifi Yazdi, M. K., \& Vahedi, S. (2015). Microbial contamination of fresh vegetable and salad samples consumed in tehran, iran. Journal of food quality and hazards control, 2(4), 139-143.

Teuber, M. (1999). Spread of antibiotic resistance with food-borne pathogens [Meeting on Evolution of Bacterial Virulence and Antibiotic Resistance, UNIV DELLA SVIZZER ITALIANA, LUGANO, SWITZERLAND, OCT 1516, 1998]. Cellular and Molecular Life Sciences, 56 (9-10), 755-763. https:// doi.org/10.1007/s000180050022

Tian, Y., Yu, H., \& Wang, Z. (2019). Distribution of acquired antibiotic resistance genes among enterococcus spp. isolated from a hospital in baotou, china. $B M C$ research notes, $12(1), 27$.

Vincenti, S., Raponi, M., Sezzatini, R., Giubbini, G., \& Laurenti, P. (2018). Enterobacteriaceae antibiotic resistance in readyto-eat foods collected from hospital and community canteens: Analysis of prevalence. Journal of Food Protection, 81 (3), 424-429. https://doi.org/10.4315/0362028X.JFP-17-317

Zhang, R., Eggleston, K., Rotimi, V., \& Zeckhauser, R. J. (2006). Antibiotic resistance as a global threat: Evidence from china, kuwait and the united states. Globalization and Health, 2. https://doi. org/10.1186/1744-8603-2-6 